\title{
Effect of Fungicide Program on the Development of Downy Mildew in Three Cucurbit Crops in New Jersey
}

\begin{abstract}
Christian A. Wyenandt, ${ }^{\dagger}$ Extension Specialist in Vegetable Pathology, Department of Plant Biology, Rutgers University, New Jersey Agricultural Experiment Station, Rutgers Agricultural Research and Extension Center (RAREC), Bridgeton, NJ 08302; Wesley L. Kline, Cumberland County Agricultural Agent, Department of Agricultural and Resource Management Agents, Rutgers University, New Jersey Agricultural Experiment Station, Rutgers Cooperative Extension, Millville, NJ 08332; and Daniel L. Ward, Extension Specialist in Pomology, Department of Plant Biology, Rutgers University, New Jersey Agricultural Experiment Station, RAREC, Bridgeton, NJ 08302
\end{abstract}

Accepted for publication 16 August 2017.

\section{Abstract}

From 2014 to 2016, five fungicide programs of varying fungicide efficacy were evaluated for the control of cucurbit downy mildew (Pseudoperonospora cubensis) on three different cucurbit crops at the Rutgers Agricultural Research and Extension Center (RAREC) in Bridgeton, NJ. The five fungicide programs were: (i) no fungicide input; (ii) low-input (chlorothalonil only); (iii) medium-input (protectant +2 downy mildew-specific fungicides [Tanos, Curzate]); (iv) high-input (protectant +2 downy mildew-specific fungicides [Ranman, Presidio]); or (v) high-input (protectant +3 downy mildewspecific fungicides [Previcur Flex, Ranman, Zampro]). The three cucurbit crops were cucumber cv. Marketmore 76, zucchini cv. Reward (summer squash), and acorn squash cv. Taybelle (winter squash). In 2014, only cucumber was infected by the pathogen. In 2015 and 2016 , all three cucurbit hosts were infected by downy mildew at varying severities suggesting that the $P$. cubensis population may have differed compared with 2014. In all three years control of downy mildew was significantly higher when downy mildewspecific fungicides were included in weekly rotations. In some years, no fungicides, broad-spectrum fungicides only, or fungicides with moderate or lower efficacy for downy mildew may provide adequate control on certain cucurbit crop species depending on the current cucurbit downy mildew pathogen population.

\section{A Changing Cucurbit Downy Mildew Population}

Cucurbit crops (Cucurbita spp.) such as pumpkin (C. pepo, C. maxima, C. moschata), summer squash (mostly C. pepo), and cucumber (Cucumis sativus) are grown in New Jersey for fresh markets along the East Coast and are widely-grown in other vegetable-producing regions of the United States and world (Cohen et al. 2015). Since 2004, cucurbit downy mildew, caused by $P$. cubensis, has caused significant losses in cucurbit crops throughout the United States (Holmes et al. 2015). The significant re-emergence of $P$. cubensis has been attributed to major changes in the population structure where genotypes, races, pathotypes, and mating types have been reported from around the world (Cohen et al. 2015; Holmes et al. 2015; Quesada-Ocampo et al. 2012; Thomas et al. 2017). Genetic diversity and pathogenicity have been shown to vary geographically in the United States and other parts of the world (Cohen et al. 2015; Savory et al. 2011; Quesada-Ocampo et al. 2012; Thomas et al. 2017). The potential presence of new or multiple races of the pathogen in the United States may make the pathogen more difficult to control using genetic resistance and fungicides with specific modes of action (Cohen et al. 2015). The presence of multiple races of the pathogen would mean that multiple genes for resistance would have to be found and bred into commercial cucurbit cultivars. Without this, fungicide use for the control of downy mildew will remain critically important for cucurbit production in the United States. Fungicides for the control of $P$. cubensis have been studied extensively in the United States since 2004 (Holmes et al. 2015). When the pathogen

${ }^{\dagger}$ Corresponding author: C. A. Wyenandt; E-mail: wyenandt@njaes.rutgers.edu

(C) 2017 The American Phytopathological Society

reemerged in 2004, there were only a few labeled fungicides that offered significant levels of control. In the past decade, fungicides with new and specific modes-of-action (e.g., Presidio, Zampro, Revus) have been registered and offer high levels of control. However, in recent years there is evidence that fungicide resistance to some of these fungicides with specific modes-ofaction has already started to develop in $P$. cubensis (Keinath, 2016; Holmes et al. 2015). Call et al. (2013) evaluated disease severity and yield of four cucumber cultivars with differing levels of resistance to $P$. cubensis with fungicide programs representing a range of efficacy. The most highly resistant cucumber cultivars required only the least effective fungicides to achieve the highest yields whereas the moderately resistant cucumber cultivars required more effective fungicides to obtain higher yields (Call et al. 2013). In the same study, the most susceptible cultivars with the most effective fungicides failed to produce the highest yields (Call et al. 2013).

Mating types (A1 and A2) of the pathogen have been found and the pathogen has been shown to sexually reproduce (i.e., produce oospores) in laboratory studies (Cohen et al. 2015; Thomas et al. 2017), but has not been found to reproduce sexually in the field in the United States to date (Holmes et al. 2015; Thomas et al. 2017). These findings suggest that the exchange of genetic information may occur within the population, which would make it much easier for the pathogen to develop or mutate into new races and allow for fungicide resistance to develop and spread within the population (Cohen et al. 2015; Holmes et al. 2015; Savory et al. 2011; Thomas et al. 2017). Studies in the United States have identified clusters of $P$. cubensis with high genetic diversities (Holmes et al. 2015; Naegele et al. 2016; Quesada-Ocampo et al. 2012). Cucurbit host preference by mating type was reported by Cohen et al. (2013) in 
Israel where mating type A1 isolates had a preference to Cucumis spp. and A2 isolates to Cucurbita spp.

Differentials have been used to identify $P$. cubensis pathotypes with varying results (Holmes et al. 2015). Additionally, surveys have shown that differences in regional diversity may or may not exist, and may be driven by regional host availability (Holmes et al. 2015; Naegele et al. 2016). Temporal studies by Naegele et al. (2016) showed population structure varied by site and sampling

\begin{tabular}{|c|c|c|c|c|c|c|c|c|c|c|}
\hline \multirow[b]{3}{*}{ Program name } & \multirow[b]{3}{*}{ Fungicide rate/hav } & $\begin{array}{l}\text { TAB } \\
\text { lues fo } \\
\text { er squ } \\
\text { Exten: }\end{array}$ & $\begin{array}{l}1 \\
\text { ive di } \\
\text { h (zuc } \\
\text { n Cen }\end{array}$ & $\begin{array}{l}\text { ent } f \\
\text { ni }{ }^{\prime} R e \\
\text { in } B r\end{array}$ & $\begin{array}{l}\text { icid } \\
\left.d^{\prime}\right) \text {, } \\
\text { ato }\end{array}$ & $\begin{array}{l}\text { progre } \\
\text { nd wir } \\
\text { NJ, fre }\end{array}$ & $\begin{array}{l}\text { for } \\
\text { squ } \\
201\end{array}$ & $\begin{array}{l}\text { eco } \\
\text { h } \\
20\end{array}$ & $\begin{array}{l}\text { l of c } \\
\text { 'Tay }\end{array}$ & $\begin{array}{l}\text { urbit } \\
\text { le') }\end{array}$ \\
\hline & & \multicolumn{3}{|c|}{ Cucumber } & \multicolumn{3}{|c|}{ Summer Squash } & \multicolumn{3}{|c|}{ Winter Squash } \\
\hline & & $2014^{w}$ & $2015^{x}$ & $2016^{y}$ & 2014 & 2015 & 2016 & 2014 & 2015 & 2016 \\
\hline UTC & none & $2608 a^{z}$ & $1741 \mathrm{a}$ & $1994 \mathrm{a}$ & - & $1675 \mathrm{a}$ & $90 \mathrm{a}$ & - & $1296 \mathrm{a}$ & $64 \mathrm{a}$ \\
\hline $\begin{array}{l}\text { High input, } \\
\text { old standard }\end{array}$ & $\begin{array}{l}2.3 \text { liter chlorothalonil }+0.20 \text { liter } \\
\text { Ranman alt. weekly with } 2.3 \text { liter } \\
\text { chlorothalonil }+0.29 \mathrm{~kg} \text { Presidio }\end{array}$ & $853 \mathrm{c}$ & $417 \mathrm{c}$ & $610 \mathrm{c}$ & - & $706 \mathrm{c}$ & $15 \mathrm{bc}$ & - & $310 \mathrm{bc}$ & $15 \mathrm{c}$ \\
\hline $\begin{array}{l}\text { High input, } \\
\text { new standard }\end{array}$ & $\begin{array}{l}2.3 \text { liter chlorothalonil }+1.4 \text { liter Previcur } \\
\text { Flex }+0.20 \text { liter Ranman alt. weekly with } \\
2.3 \text { liter chlorothalonil }+1.4 \text { liter Previcur } \\
\text { Flex }+0.98 \text { liter Zampro }\end{array}$ & $806 \mathrm{c}$ & $373 \mathrm{c}$ & $633 \mathrm{c}$ & - & $517 \mathrm{c}$ & $0 \mathrm{c}$ & - & $250 \mathrm{c}$ & $10 \mathrm{c}$ \\
\hline
\end{tabular}

${ }^{\mathrm{v}}$ Fungicide program and application rates.

${ }^{\mathrm{w}}$ Fungicide application timing in 2014: $1=8 / 7,2=8 / 13,3=8 / 20,4=8 / 26,5=9 / 1,6=9 / 8,7=9 / 15,8=9 / 23,9=9 / 29,10=10 / 7$.

${ }^{\mathrm{x}}$ Fungicide application timing in 2015: $1=7 / 29,2=8 / 6,3=8 / 13,4=8 / 19,5=8 / 27,6=9 / 3,7=9 / 9,8=9 / 17,9=9 / 24$.

${ }^{\mathrm{y}}$ Fungicide application timing in 2016: $1=8 / 8,2=8 / 16,3=8 / 24,4=8 / 31,5=9 / 7,6=9 / 14,7=9 / 21$.

${ }^{\mathrm{z}}$ AUDPC values followed by the same letter are not statistically different from each other, Fisher's Protected LSD $(\alpha=0.05)$.

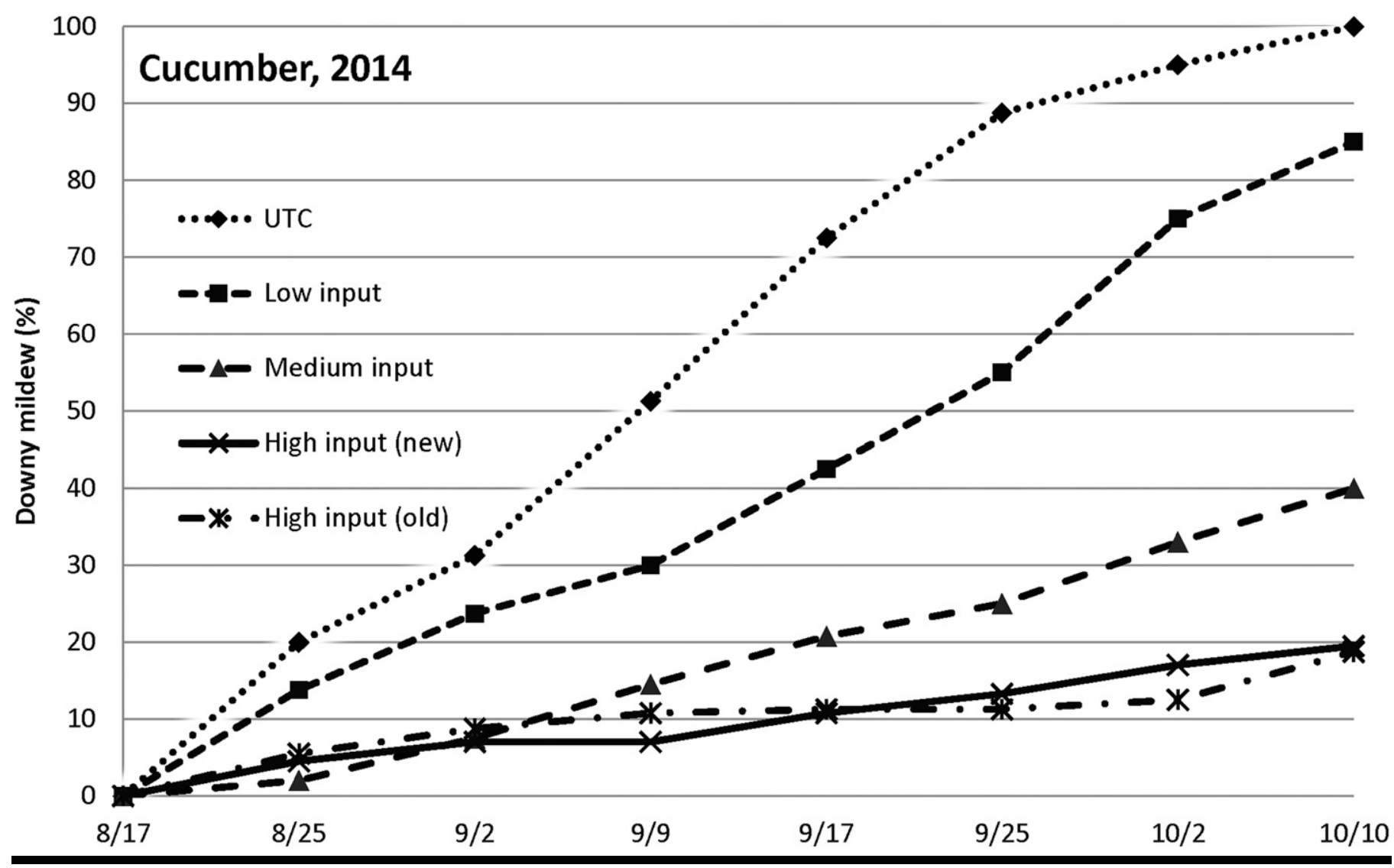

FIGURE 1

Downy mildew development (\%) in cucumber 'Marketmore' under five different fungicide programs at the Rutgers Agricultural Research and Extension Center (RAREC) in Bridgeton, NJ, in 2014. 
date within a growing season in Michigan and Ontario; the variation was low but consistent with the idea of a gradual migration of isolates into the region. Thomas et al. (2017) detected both cucurbit downy mildew mating types, A1 and A2, in the United States and determined that isolates of mating type A1 were mostly found on cucumber (Cucumis spp.) and isolates of mating type A2 (Cucurbita spp.) were mostly found on squash and watermelon in accordance with Cohen et al. (2013). Thomas et al. (2017) determined that mating type was associated geographically where isolates collected from northern states (i.e., Michigan, New Jersey, New York, and Ohio) were all mating type A1 and isolates collected in southern states (i.e., Alabama, Florida, Georgia, North Carolina, South Carolina, and Texas) belonged equally to either mating type A1 or A2. Importantly, this work showing that both mating types (A1 and A2) were present in the southern United States help demonstrate that the pathogen could reproduce sexually (Thomas et al. 2017).

The objectives of this study were to evaluate five fungicide programs for downy mildew control on three different cucurbit hosts (cucumber, squash, and pumpkin) in southern New Jersey.

\section{Downy Mildew Population and Fungicide \\ Efficacy Programs}

From 2014 to 2016, five different fungicide programs with expected varying fungicide efficacy were evaluated at the Rutgers Agricultural Research and Extension Center (RAREC) in Bridgeton, NJ, on three different cucurbit crops. The five fungicide treatment programs, which are listed in Table 1, were: (i) no fungicide input (untreated control [UTC]); (ii) a low fungicide (protectant fungicide only) input; (iii) medium input (protectant +2 older downy mildew-specific fungicides [Tanos, Curzate]); or (iv) high fungicide input (protectant + 2 newer downy mildew-specific fungicides [Ranman, Presidio]), (old commercial standard); or (v) high fungicide input (protectant + 3 newer downy mildew-specific fungicides) fungicides [Previcur Flex, Ranman, Zampro] (new commercial standard). The three cucurbit crops evaluated were cucumber cv. Marketmore 76, zucchini cv. Reward (summer squash), and acorn squash cv. Taybelle (winter squash). In each year, raised beds were covered with white plastic on 1.5-m centers with one drip-irrigation line offset to one side. Plots were one row, $4.6 \mathrm{~m}$ long, with $1.5 \mathrm{~m}$ between beds, and arranged in a randomized complete block design with four replications. Plots were hand seeded ( 2 seeds/hole) at 0.3 -m spacings on 22 July 2014, 17 July 2015, and 19 July 2016 and reseeded as needed one week later. The field was fertilized preplant incorporated with $56 \mathrm{~kg} / \mathrm{ha}$ nitrogen (calcium nitrate). The remainder of the fertilizer was applied through the drip system at the rate of $34 \mathrm{~kg} / \mathrm{ha}$ as $20-20-20$ equivalent as needed during the study. Prowl at 4.67 liter/ha with Dual Magnum at 2.33 liter/ha and Sandea 0.75 oz/acre were applied then followed with an application of Dual Magnum at 1.16 liter/ha with Command at 0.3 liter/ha for weed control.

The five fungicide programs were initiated on 7 Aug 2014, 29 July 2015, and 8 Aug 2016 and applied every 7 to 10 days for a total of 10 applications in 2014, 9 applications in 2015, and 7 applications in 2016. All fungicide treatments were applied with a pressurized tractor-mounted sprayer with three hollow-cone D4-25, disc core drop nozzles (one over the top, one on each side of the row at a 45 degree angle) at 43 gal/acre and 58 psi. Plots were evaluated for downy mildew development from August until October each year. Foliage was rated weekly on a scale of 0 to $100(0.0=$ no downy mildew; $100=100 \%$ of leaves infected) for downy mildew development. Arcsine-transformed area under disease progress curve (AUDPC) value for downy mildew development was calculated for each fungicide program in each year. No harvests were done.
Downy Mildew Population and Fungicide Program Will Affect Control Strategies

In 2014, cucurbit downy mildew appeared late in the production season about one month after seeding and approximately two weeks after the first fungicide application. Importantly, during the course of study only cucumber 'Marketmore 76' became infected by the pathogen (Fig. 1). This suggests, along with other reports in the region, that the primary host for cucurbit downy mildew in 2014 was cucumber, suggesting that the pathogen may have a predominant race(s) develop in any specific growing season. Area under disease progress curve (AUDPC) values varied significantly based on fungicide

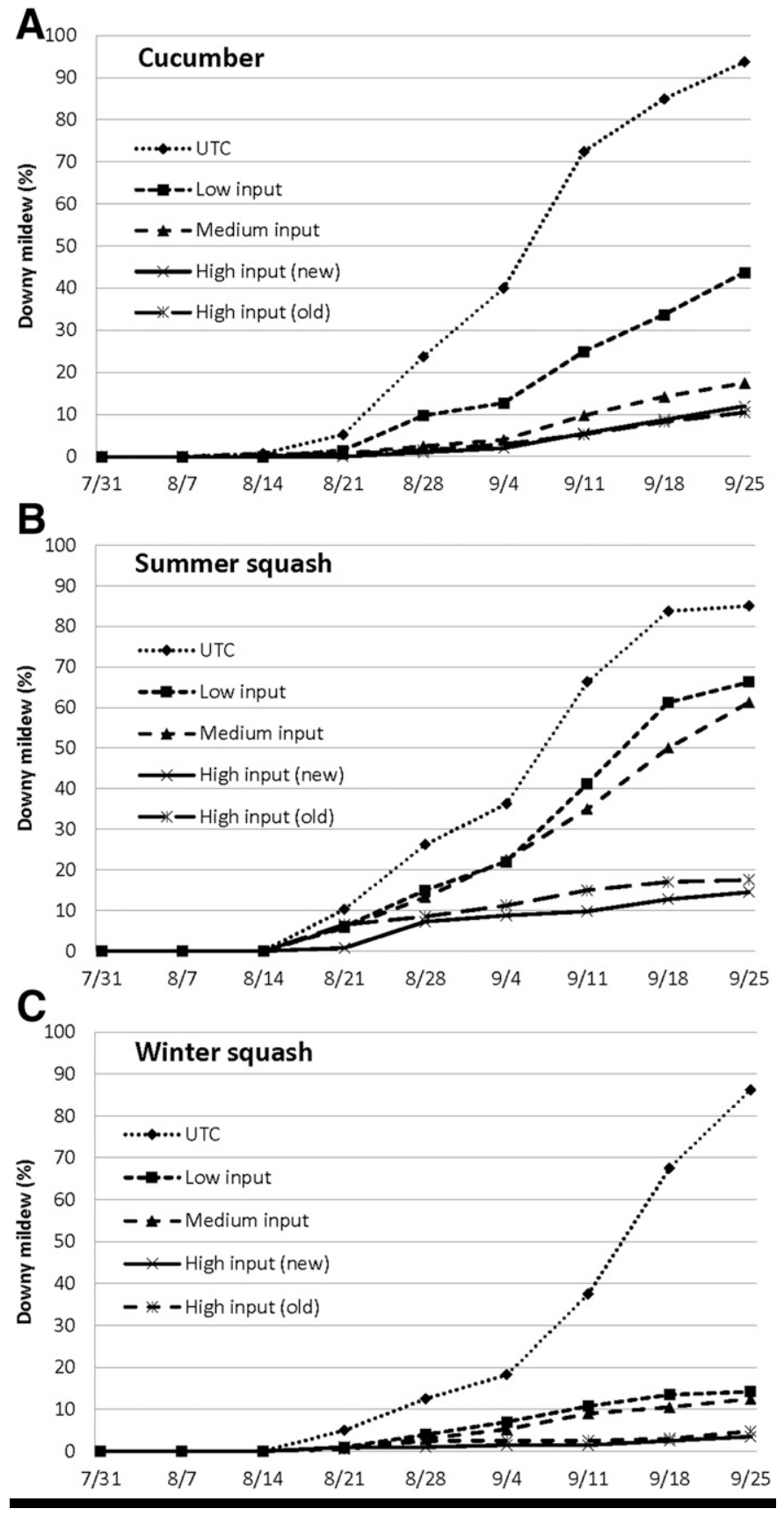

FIGURE 2

Downy mildew development (\%) in (A) cucumber 'Marketmore 76', (B) summer squash (zucchini 'Reward'), and (C) winter squash (acorn 'Taybelle') across five different fungicide programs at the Rutgers Agricultural Research and Extension Center in Bridgeton, NJ, in 2015. 
program (Table 1). In cucumber in 2014, AUDPC values were significantly higher in the UTC and low-input programs compared with the medium and high-input fungicide programs for cucurbit downy mildew control (Table 1). Control was similar between the medium and two high-input fungicide programs (new and old standard; (Table 1). Although not significantly different, both highinput fungicide programs resulted in numerically lower AUDPC values (Table 1) suggesting slightly better downy mildew control compared with the medium-input program (Table 1).

In 2015, cucurbit downy mildew appeared late in the production season about 1 month after seeding and approximately 2 weeks after the first fungicide application. Unlike 2014, cucurbit downy mildew developed on summer squash (zucchini) and winter squash (acorn) as well as cucumber in 2015 (Fig. 2). There was a significant interaction between fungicide program and crop in 2015 and AUDPC values are presented by crop (Table 1). On cucumber, the medium, high-input (old standard), and high-input (new standard) fungicide programs all significantly reduced cucurbit downy mildew compared with the low-input and UTC (Table 1). On summer squash, the high-input programs (old and new standards) significantly reduced cucurbit downy mildew compared with the UTC, low-input, and medium-input fungicide programs suggesting that fungicide programs with rotations of cucurbit downy mildew-specific fungicides on a weekly basis provided more effective control of cucurbit downy mildew (Table 1). On winter squash, the low, medium, highinput (old standard), and high-input (new standard) all significantly reduced cucurbit downy mildew compared with the UTC (Table 1). However, only in the high-input (new standard) was AUDPC value significantly lower than the low-input and UTC (Table 1). The low-, medium-, and high-input (old standard) were all similar in control and significantly lower than the UTC (Table 1).

In 2016, cucurbit downy mildew appeared late in the production season about one month after seeding and approximately two weeks after the first fungicide application (Fig. 3). Unlike 2014, cucurbit downy mildew also developed on all three cucurbit crops in 2016. Like previous years, cucurbit downy mildew development was highest on cucumber in 2016, although development was much lower on summer squash and winter squash $(<4 \%$ in UTC controls and $2 \%$ or less when fungicides were applied) (data not shown). Although significantly better on both the high-input and low-input programs compared with the UTC, overall percent disease development and AUDPC values for cucurbit downy mildew pressure on summer and winter squash crops in 2016 were too low to make meaningful comparisons (Table 1).

Results of this study suggest that different race(s) of cucurbit downy mildew may be entering into the mid-Atlantic region annually and that cucurbit host susceptibility and fungicide control may vary greatly from year to year. In 2014, only cucumber became infected at RAREC, and only fungicide programs containing newer, more specific downy mildew fungicides effectively controlled the disease. In 2015 and 2016, all three cucurbit host crops were infected by downy mildew; and summer squash and cucumber were more severely affected than winter squash. Differences in $P$. cubensis infection on different Cucurbita spp. have been reported in other studies (Cespedes-Sanchez et al. 2015; Holmes et al. 2015). In the mid-Atlantic region, $P$. cubensis is most likely coming into the

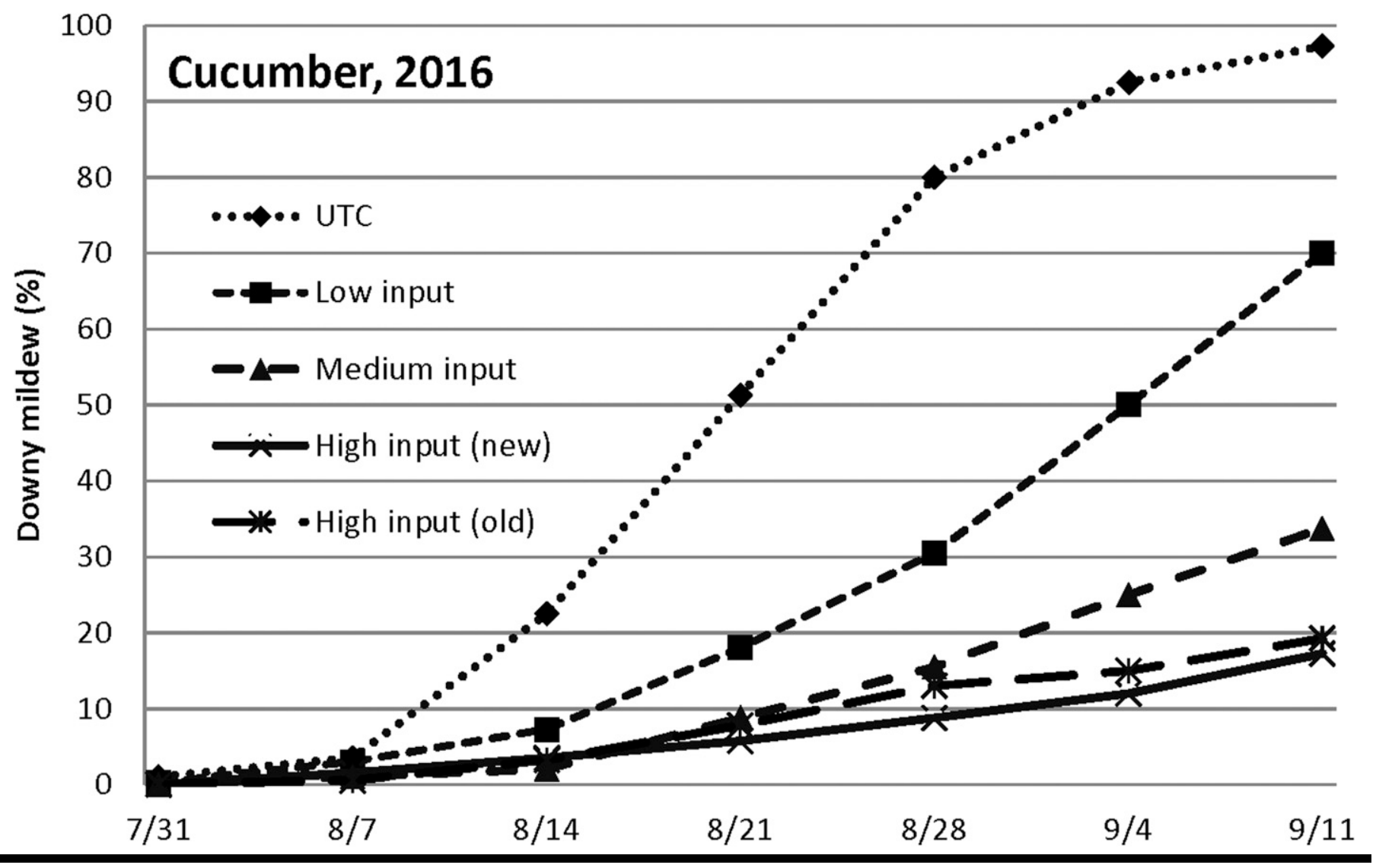

FIGURE 3

Downy mildew development (\%) in cucumber 'Marketmore' under five different fungicide programs at the Rutgers Agricultural Research and Extension Center (RAREC) in Bridgeton, NJ, in 2016. 
region on weather patterns that carry the pathogen from the southeast each production season (Ojiambo and Holmes, 2011). In New Jersey, the first reports of $P$. cubensis have occurred on 11 August 2010; 29 June 2011; 30 May 2012; 6 August 2013; 22 July 2014; 9 July 2015; and 11 July 2016 for the past 7 years, respectively. The $P$. cubensis population entering the mid-Atlantic region each production season will determine the potential host range and control of $P$. cubensis on an annual basis. All cucurbit growers in New Jersey and throughout the mid-Atlantic region need to follow reports of cucurbit downy mildew during the production season through the Cucurbit Downy Mildew Forecasting website hosted by NCSU at http://cdm.ipmpipe.org. By following up-todate reports through the CDM forecasting website and via timely reports via the Plant and Pest Alert System growers in New Jersey and the region will be able to determine which cucurbit crops are affected, where the pathogen is located in the United States, and which cucurbit crops are most at risk. Control of cucurbit downy mildew begins with regular scouting, keeping up with reporting, recognizing the symptoms, and preventative fungicide programs. In this study, the best control of cucurbit downy mildew was in fungicide programs that contained downy mildew-specific fungicides such as Ranman, Presidio, Zampro, and Previcur Flex used in rotations or tank mixes on a weekly basis. These fungicides in combination with protectants such as chlorothalonil, Gavel, or mancozeb, or in tank mixes or rotation with other fungicides, should be used according to their respective labels. Results also demonstrate that in some instances more broad-spectrum fungicides such as chlorothalonil or mancozeb or fungicides with moderate or lower efficacy for downy mildew [(and lower chances for resistance development (e.g., Tanos, Curzate, Gavel, Phosphites)] may provide adequate control of downy mildew on certain cucurbit crops. These fungicides must also remain an important part of cucurbit downy mildew control programs and resistance management strategies. Importantly, possible resistance to fluopicolide has been detected in the mid-Atlantic region and resistance to azoxystrobin and mandipropamid has been detected in the Southeast region of the United States (Keinath 2016). The efficacy of all high-risk fungicides for cucurbit downy mildew control should be closely monitored for resistance development each growing season. Additional research is needed on the population structure of $P$. cubensis and which mating types and clades may be present and/or entering the mid-Atlantic region each production season.

\section{Acknowledgment}

This work was sponsored by the 2014 and 2015 Charles and Lena Maier Vegetable Research Award presented by the New Jersey Vegetable Growers Association (NJ-VGA). We would like to thank the Master Gardener Program of Cumberland County, New Jersey, for their continued support.

\section{Literature Cited}

Call, A. D., Wehner, T. C., Holmes, G. J., and Ojiambo, P. S. 2013. Effects of host plant resistance and fungicides on severity of cucumber downy mildew. HortScience 48:53-59.

Cespedes-Sanchez, M. C., Naegele, R. P., Kousik, C. S., and Hausbeck, M. K. 2015. Field responses of cucurbit hosts to Pseudoperonospora cubensis in Michigan. Plant Dis. 99:676-682.

Cohen, Y., Rubin, A. E., and Galperin, M. 2013. Host preference of mating type in Pseudoperonospora cubensis, the downy mildew causal agent of cucurbit. Plant Dis. 97:292.

Cohen, Y., Van den Langenberg, K. M., Wehner, T. C., Ojiambo, P. S., Hausbeck, M., Quesada-Ocampo, L. M., Lebada, A., Sierotzki, H., and Gisi, U. 2015. Resurgence of Pseudoperonospora cubensis: The causal agent of cucurbit downy mildew. Phytopathology 105:998-1012.

Holmes, G. J., Ojiambo, J., Hausbeck, M. K., Quesada-Ocampo, L., and Keinath, A. P. 2015. Resurgence of cucurbit downy mildew in the United States: A watershed event for research and extension. Plant Dis. 99:428-441.

Keinath, A. P. 2016. Utility of a cucumber plant bioassay to assess fungicide efficacy against Pseudoperonospora cubensis. Plant Dis. 100:490-499.

Naegele, R. P., Quesada-Ocampo, L. M., Kurjan, J. D., Saude, C., and Hausbeck, M. K. 2016. Regional and temporal population structure of Pseudoperonospora cubensis in Michigan and Ontario. Phytopathology 106:372-379.

Ojiambo, P. S., and Holmes, G. J. 2011. Spatial temporal spread of cucurbit downy mildew in the eastern United States. Phytopathology 101:451-461.

Quesada-Ocampo, L. M., Granke, L. L., Olsen, J., Gutting, H. C., Runge, F., Thines, M., Lebeda, A., and Hausbeck, M. K. 2012. The genetic structure of Pseudoperonospora cubensis populations. Plant Dis. 96:1459-1470.

Savory, E. A., Granke, L. L., Quesada-Ocampo, L. M., Varbanova, M., Hausbeck, M. K., and Day, B. 2011. The cucurbit downy mildew pathogen Pseudoperonospora cubensis. Mol. Plant Pathol. 12:217-226.

Thomas, A., Carbone, I., Cohen, Y., and Ojiambo, P. S. 2017. Occurrence and distribution of mating types of Pseudoperonospora cubensis in the United States. Phytopathology 107:313-321. 